1 Universidade Federal de Santa Catarina (UFSC), Laboratório de Tecnologia e Inovação na Educação, Pesquisa e Extensão em Atenção Psicossocial e Drogas (Apis) Florianópolis (SC), Brasil. alerafaloski@gmail.com

2 Universidade Federal de Santa Catarina (UFSC),

Departamento de Saúde Pública - Florianópolis (SC), Brasil.

\section{Mental health of people involved in natural disasters from the perspective of the workers involved}

\author{
Saúde mental das pessoas em situação de desastre natural sob a ótica \\ dos trabalhadores envolvidos
}

Alessandra Rossoni Rafaloski1, Maria Terezinha Zeferino', Bárbara Aparecida Oliveira Forgearini1, Gisele Cristina Manfrini Fernandes', Fabrício Augusto Menegon²

DOI: 10.1590/0103-11042020E216|

\begin{abstract}
The phenomenon of disaster causes serious impacts on the population that is directly or indirectly involved. This study aimed to understand the psychosocial care to people in disaster situation in the municipality of Blumenau, from the perspective of the workers involved. This is a qualitative, descriptive exploratory research, conducted in the context of a municipality with recurrent natural disasters that mark the history of the population. Data were collected through semi-structured interviews with health, civil defense, and fire brigade workers, selected by the Snowball technique. Data were analyzed by the content analysis method. As a result we describe three units of analysis: Unexpected event with unprepared population; Increase in the number of people in psychological distress and aggravation of cases already under treatment; Current strategies of the municipality, discussing the concepts of crisis, trauma and disruptive syndrome as effects on mental health in disaster situations. It is concluded that psychosocial care in disaster situation needs to go further, as it should be more active in prevention, during and after disaster, ensuring integral care to all people involved.
\end{abstract}

KEYWORDS Mental health. Natural disasters. Impact. Psychosocial impact. Health worker.

RESUMO O fenômeno do desastre causa sérios impactos à população que está direta ou indiretamente envolvida. Este estudo teve como objetivo compreender a atenção psicossocial às pessoas em situação de desastre no município de Blumenau na ótica dos trabalhadores envolvidos. Trata-se de uma pesquisa qualitativa, exploratória, descritiva, realizada no contexto de um município com recorrentes desastres naturais que marcam a história da população. A coleta de dados se deu por meio de entrevistas semiestruturadas, realizadas com trabalhadores do setor saúde, defesa civil e corpo de bombeiros, selecionados pela técnica Bola de Neve. Os dados foram analisados pelo método de análise de conteúdo. Como resultado, descrevem-se três unidades de análise: Evento inesperado com a população desprevenida; Aumento do número de pessoas em sofrimento psíquico e agravo dos casos já em tratamento; Estratégias atuais do município, discutindo-se os conceitos de crise, trauma e síndrome disruptiva como efeitos à saúde mental nos desastres. Conclui-se que a atenção psicossocial na situação de desastre precisa ir além, deve estar mais atuante na prevenção, durante e no pós-desastre, garantindo o cuidado integral a todas as pessoas envolvidas.

PALAVRAS-CHAVE Saúde mental. Desastres naturais. Impacto psicossocial. Trabalhador da saúde. 


\section{Introduction}

A disaster is defined by the National Civil

Defense as

[...] the outcome of adverse events, natural or caused by humankind, on a vulnerable ecosystem, resulting in human, material, and/or environmental damages and consequent economic and social loss $\mathbf{1}$.

These are disruptive episodes with great potential to physical and mental disorders, in which susceptible people are those directly or indirectly affected, the workers involved, and even those who follow the event through communication media ${ }^{2}$. In such an adverse context, the population's mental health becomes an easy target, demanding from workers in psychosocial care the development of actions to deal with this condition. However,

[...] the amount of qualified personnel in this subject is not always proportional to the needs, because for each person with a physical wound there are at least two hundred who need assistance (not treatment) in the area of mental health2(88).

The great potential of the impact of disasters on the population reveals the importance of the work in all spheres, grounded on mental health knowledge to provide the population and also professionals with activities that promote prevention, mitigation, and treatment in mental health.

Therefore, understanding people's subjective experiences in a context of disaster and in post-disaster overcoming, denotes how the affected persons perceive their social world after a trauma experience and enables listening to them, thus legitimizing the suffering that emerges from these life situations and creating the opportunity to understand the suffering, which is often marginalized and made invisible as time passes ${ }^{3}$.

The Practical guide on mental health in disasters ${ }^{4}$ refers that in a disaster situation often the subject is abruptly faced with reality. At that moment, the nervous system is altered and can affect immunological responses; the person can experience intense emotional sensations that may range from paralyzing fear to disordered agitation, from extreme pain to absence of pain. After the disaster, great fear and anxiety may continue, then give way to sadness and irritability sensations. There may also appear psychosomatic symptoms such as pain and aggravations in general.

The pain may be intensified when material and personal losses occur. The subject must deal with grief and a new adaptation of life. In this sense, readaptation will be facilitated when the subject encounters psychosocial support and this intervention cannot be limited to specialized services. It must be present in the actions of all workers involved, in such a way that mental health care is offered to all those affected by a disaster.

The Itajaí Valley region, in the state of Santa Catarina, Southern Brazil, has recurrent disasters that mark the history of its population; therefore, it demands from services certain attention and care strategies. Disasters in this region of the country have been the object of studies in various fields, including health ${ }^{5}$. The disaster to which these studies refer occurred in November 2008; it struck many Itajaí Valley municipalities following intensive volume of rain, causing precipitation and inundation that in combination with torrents culminated in landslides. The level of Itajaí-Açu river reached 11.52 meters; in Blumenau, the municipality chosen for this study, approximately 103 thousand people were affected; 5,209 were displaced, with 25 thousand people sheltered in the homes of neighbors, relatives and friends; 2,383 persons were wounded and 24 lost their lives $^{6}$. It is important to understand that the intensity of a disaster depends not only on the event's magnitude, but also on the affected locality's degree of vulnerability, turning the natural disaster, in fact, into a socially constructed phenomenon? ${ }^{7}$. 
Vulnerability is understood here as a social condition of factors originated from environmental changes and social processes. Environmental changes are understood as those occurring due to environmental degradation, such as deforestation of rivers and igarapés slopes and beds, pollution, among others; social processes are understood as those resulting from the precariousness of life conditions and social protection, such as lack of access to services, unemployment, lack of sanitation and drinking water, poor housing, among others $\mathbf{7 , 8}$.

Among the greatest causes of the increase of socio-environmental vulnerability are the economic, cultural, and social processes that triggered accelerated and disorganized population growth in certain localities, leading to increased numbers of dwellings built in inadequate areas without sanitation. Another important causes are the implemented models of natural resources exploitation and agricultural and industrial production ${ }^{8}$. Disasters are engendered by the combination of conditions that lead to socio-environmental vulnerability together with social and economic inequality; this relationship results in catastrophes that produce greater consequences in poor countries with less governance capability ${ }^{9}$.

In Brazil there is a lack of available documents on the issue of disasters focusing on mental health. A bibliographic search pointed some material, such as the National Joint Protocol for Integral Protection of Children and Adolescents, Elderly Persons and Disabled Persons in Conditions of Risks and Disasters produced by the Secretariat of Human Rights of the Presidency of the Republic (SDH/PR), of the Ministry of Justice and Citizenship ${ }^{\mathbf{1 0}}$, and the Guide for preparedness and response to disasters associated to inundations for municipal management of the Unified Health System (SUS) ${ }^{11}$ produced by the Secretariat of Health Surveillance of the Ministry of Health, with guidance to services held by professionals in disaster situations. However, these materials do not elaborate further on issues related to psychosocial care; there are gaps regarding practical actions so that professionals may effectively work in these disaster situations.

Therefore, the aim of this study is to describe mental health professionals' viewpoint on mental health of individuals involved in a disaster situation in the municipality of Blumenau, state of Santa Catarina (SC), Brazil.

\section{Material and methods}

This is a qualitative, exploratory, and descriptive research. The research setting was the municipality of Blumenau, Itajaí Valley, in the Northern part of the state of Santa Catarina, Brazil. Blumenau has a territorial area of 518.497 square kilometers and an estimate population in 2015 of 338,876 inhabitants ${ }^{\mathbf{1 2}}$. The main economic activities are textile and technology industries. Geographically it presents uneven altitudes and declivities, humid subtropical climate, and Itajaí-Açu river runs across the municipality. Its culture is characterized by the presence of descendants of German and Italian immigrants who colonized the region. The Human Development Index (HDI) is 0.806 , higher than the national average of $0.792^{13}$.

The municipality was chosen as object of the research because it presents a history of frequent inundation and flooding, according to the Civil Defense ${ }^{\mathbf{1 4}}$ that registered 77 flooding in the municipality from October 1952, when data started to be recorded, until September 2011. It is considered a flooding when Itajaí river rises eight meters above its means level. When a disaster occurs the municipal government coordinates its secretariats to operate their actions in a combined way. In the case of this study, drawing on the health sector where psychosocial care is inserted, the research also included respondents from the Civil Defense and the Military Fire Brigade of the state of Santa Catarina.

For the selection of respondents, the research utilized the snowball technique, also 
known as chain referral, which uses the relationship between people, i.e., it uses a sample as reference as a means to add members to the research ${ }^{15}$. Among the participants of the research there were: health professionals, with two nurses, two psychologists, one social worker; the other workers involved were: one from the civil defense and one from the Military Fire Brigade.

Data collection was made using semistructured interviews. All interviews were conducted based on a previously structured guide with themes for exploration and development.

To carry out the first interview, an e-mail was previously sent to the mental health coordination, explaining about the research and the need for an indication of a management staff who would provide the initial data. Drawing on the first indication all the others then followed.

Data analysis followed the steps of content analysis ${ }^{16}$ in accordance with the literature on the theme and had as reference the "Guide for preparedness and response to disasters associated to inundations for municipal management of SUS'11 and the 'Practical guide on mental health in disasters' 4 . The outcomes were presented in a descriptive way, as shown in the results and discussion section that follows.

This research complied with Resolution $n^{0} 466 / 12$ of the National Council of Health ${ }^{17}$; it is linked to the macro-project of the Laboratory of Technology and Innovation in Education, Research and Extension in Psychosocial Care and Drugs (Apis) of the Federal University of Santa Catarina (UFSC) in Florianópolis, state of Santa Catarina (SC), submitted to and approved by the UFCS Ethics Committee for Research with Human Beings under number 924.432/2014. In order to guarantee participants' anonymity, each worker received the letter $\mathrm{T}$, which is the initial letter of the word 'worker' in Portuguese ('trabalhador'), followed by a numeral from 1 to 7 for data presentation.

\section{Results and discussion}

Three categories of analysis have emerged in this study: unexpected event with unprepared population; Increase in the number of people with mental distress and aggravation of cases already under treatment; Current strategies of the municipality.

Unexpected event with unprepared population: this category describes that the population only expected and was prepared for a river level rise; people and workers were suddenly confronted with landslide, which due to being unexpected affected many people.

Many people went up, not to be caught by inundation. What happened in 2008 was the great differential of natural disasters. I think it was three months of continued rainfall, to the point when these hills started to slide and then it reached a large number of people directly in the city. There were spots considered noble places that until then had been immune, everything was lost. (T1).

There were many communities with good infrastructure that no one would have imagined that could fall and that year it happened, so it caught everyone unprepared, where you would have never imagined that there would be a landslide... there was. (T3).

Today we can make a 24 hours forecast if there is going to be an inundation; what we are still learning is about landslide. (T5).

Data reveal that the impact on the population's way of reacting, previously accustomed to facing inundation, seems to have changed after the 2008 event due to the type of disaster that associated landslide to widespread flooding, causing extensive damage to the population that was suddenly confronted with other environmental risks and the imminence of harm to mental health.

The population lives in the city's territory whose inundation risks has been known; but increasing urbanization along the years, 
together with problems in infrastructure and planning, culminated in the occupation of higher areas nearby hillsides. In these sites there are varying characteristics regarding social vulnerability, according to housing types and household economic conditions. The Hyogo Framework for Action (HFA), which seeks the implementation of disaster risk reduction, defines vulnerability as

[...] certain conditions determined by physical social, economic, and environmental factors or processes that increase a community's susceptibility to the impact of risks ${ }^{18(5)}$.

The affected persons were from all social classes and most regions in the municipality; this situation impacted the population in a generalized manner and this was related to the local vulnerability at the time of the disaster.

When the disaster occurred, warnings were made about inundation. There was no warning about landslides. Thus, the situation experienced was considered extreme, due to having occurred in an unexpected and severe way, altering life routine of the affected persons ${ }^{19}$.

In the conditions in which the rupture of reality occurred, trauma breaks mental organization and causes an annulation of life's continuity. The intensity of what is experienced hampers the elaboration of its contents, which may give rise to the symptom of breaking bonds of affection. Without inner resources to deal with this situation, everything seems senseless, turning into something forsaken and distressing ${ }^{20}$. The mind has the capacity to select stimuli that can be received and processed as to maintain adequate psychic energy for the development of normal mental processing. The mind articulates and relates experiences between them, creating a complex experiential and lived chain $\mathbf{2 , 2 0}$.

Trauma is a concept that relates to the context of disaster, named disruptive syndrome, understanding that an actual event of disaster becomes disruptive when something is disorganized, loses its structure, and breaks up the life that was in balance until then ${ }^{2}$. The singularity in which each person internalizes the real fact reflects also on the impacts of a certain event, i.e., disruptive is a relational concept that has a relativistic potential. Therefore, the mental reaction is determinant to be considered disruptive ${ }^{2}$.

Streets and neighborhoods suddenly no longer existed due to landslides; in these sites, relationships were destroyed, lost their familiar reference of people who used to live nearby. The interruption of the natural process of life - a disaster, for example - can have different interpretations among people: some have a perception that the threat is part of their own subjectivity and that they will not find the strength to deal with what happened; but for others this is a situation that brings sentiments of solitude, social isolation, self- and hetero-aggressiveness, among others ${ }^{2}$.

For the understanding of the concept of disruptive it is important to consider the different ways of perceiving the same event that engenders mental distress for some individuals and not for others. This concept reminds that of resilience that means recovering and adaptation. It refers to the human being's capacity to adapt and not enter into distress or become vulnerable at the moment of the occurrence or after a crisis ${ }^{\mathbf{2 1}}$. Resilience in a disaster situation refers to the concept of community resilience, which corresponds to the community's resources and capacities to recover when exposed to a disaster situation.

A resilient community engenders selforganization, adaptation, and learning. The resilient community has the capacity to recognize its region's risks and become prepared, establishing plans for the mitigation of risks ${ }^{\mathbf{2 1}}$. Hence, both concepts relate to the individual's perception; the disruptive, when the process occurs in a negative way causing distress; and resilience, when a positive and healthy process leads to adaptation. 
There is a potential for falling ill as emotional and/or mental disorder, when populations are lengthily exposed to natural disruptive events; it configurates a symptomatic pattern feedback, in which unresolved loss and grief engender an immense mental distress for those individuals ${ }^{2}$.

Increase in the demand for mental health services following a disaster and in the number of diagnoses: this category refers to the increase in the number of persons who seek mental health care, and consequently in the amount of new diagnosed cases.

There were families with no mental health disorders, but from that tragedy on they became patients of mental health care. Why? When their houses fell, their lives fell! All they had was the house, when she woke up that night she didn't have the house anymore, she went into distress, and this affected the husband, the children and all the structure they had built, that day, that night in 2008 the dream was over, they had losses that were not only material, many people lost their children and other relatives were buried in the landslide. Besides, they went to a neighborhood where they had no references, they became distressed and it reflects in their mental health [...]. (T3).

People used to say that this city that used to be healthy was now cut through by this phenomenon that disorganizes the entire city, all people are affected. [...] what we observe in the mental health services is that this collective shadow is still there. There is the damage triggered by the catastrophe, situations that were already stable, they became unbalanced again in terms of chemical addiction in the use of substances and becoming ill. (T2).

So we perceive the initial commotion in the first moment. But I perceived along the years what comes afterwards, which is the population's aggressiveness, intolerance, the immediatism of what people want. So, what greatly lacks and is extremely important for this population is the posttragedy care to know how to resume life after what happened. Start again from where life stopped!
What we saw a lot in the Care Unit was the population seeking care, there was a huge increase of people using some kind of sleeping medicine, for anxiety and other situations. (T5).

Families arrive completely fragilized, they lost their goods, lost their homes and in some cases they must have this mental support. (T4).

In the aftermath of the disaster in the municipality under study, there was a significant increase in the demand for health services, particularly for mental health. In this sense, it is important to deliver primary mental health care, especially free of unnecessary medicalization of symptoms. It is important to prepare the team workers so that they have previous knowledge on how to act and identify symptoms and aggravation triggered by a disaster situation ${ }^{\mathbf{8 , 2 2}}$. Approaching the disaster as a socio-environmental disaster means broadening the perception of the event as such, the community participation as a way to prevent it, and in the post-disaster having the means to evaluate the context and the existing social structures of the place, considering the importance of these conditions to overcome the difficulties met with ${ }^{19}$.

The respondents observe in the clinic that there are cases of mental aggravation that may be related to the experience of the 2008 disaster; there are also situations of individuals who were already stabilized in their treatments but the event triggered disorders such as symptoms of depression, panic syndrome, and quite often associated anxiety disorders. The psychological reflection of disasters affects individuals differently and this is related to the psychological structure and the event's dimension. However,

[...] disasters aggravate the risks of previously existing diseases in the locality; therefore it is crucial to understand how health prevention actions are conducted in consonance with those of disaster health risks prevention ${ }^{7,8}$. 
In other words, this is a risk factor that cannot be overlooked. It is a population with greater fragility that must receive priority care. The risk group must be preventively mapped and monitored previously to the occurrence of a disaster situation. Thus, the work must be preventive and dynamic in the formal and informal networks of care; the knowledge of the relationships that people in the community have with relatives, schools, and neighbors before the disaster contributes to a systemic understanding for the actions of professionals in post-disaster ${ }^{22}$.

But also individuals who were already under mental health treatment, with or without psychiatric medication, must have guaranteed care after the occurrence of the disaster ${ }^{23}$. These are demonstrations of how important it is to have Contingency Plans of the Secretariat of Health in order that workers know what the population's needs will be at that moment. It is interesting that health teams identify their clientele in psychiatric treatment, considering that mental and psychosocial problems may intensify distress in a situation of emergency and disaster. In this risk group are included those people with alcohol and drugs abuse because the occurrence of a disaster is a stressing factor that may lead to the intensification of abuse and its negative effects, creating difficulties to find support networks and adhere to treatments after the disaster ${ }^{4}$.

Regarding post-traumatic stress, housewives present four times greater risk of developing suicidal ideation after a disaster. The risk is even greater in developing this ideation when there are relatives affected by the situation of disaster; twelve among twenty-two persons who previously had suicidal ideation present symptoms of Post-Traumatic Stress Disorder (PTSD) ${ }^{24}$. The stress is related to experiencing the post-disaster crisis and grief resulting from losses, which are multiple, unexpected, and varied in disaster situations: the loss of life as it used to be, material loss, death or personal aggravations ${ }^{5}$. Grief is associated with meaningful losses that may occur in an individual's life and that in a disaster situation also disorganizes the person's life. But among the affected population and the care delivered in response to disasters or in the period of recovery from disasters, there are professionals from various areas who are also directly or indirectly affected by such events and may also experience their grief and suffer impacts on their mental health.

Current strategies of the municipality: some strategies that started in the 2008 disaster or were enhanced by it were put into effect in the municipality. We have identified two strategies that correspond to the mental health of the population involved: Matrix Support and Permanent Education.

In the context of the 2008 disaster, health services had already been using Matrix as a work tool in the Psychosocial Care Centers (Caps), of the Secretariat of Education and Social Assistance; but with the organization that was built in the post-disaster and the implementation of Ordinance nr 3088 in that same year, the network became more structured and coordinated, also among health services, according to the following report:

From the end of 2008, 2009 we started with the follow-up matrix ordinance and have been working up to now in a more structured way... our great tool of interchange in basic care, working in all aspects of psychosocial care is the Matrix Support. (T1).

Permanent Education, in its turn, has been categorized as health strategy. The sector is mobilized to provide courses to workers; however, the courses are not yet comprehensive and systematic, as stated in the following report: "We have the preparation from our education, but there has never been a formal capacitation for assistance during and posttragedy" (T5).

The various traumatic situations experienced by the population and workers have resulted in that some punctual strategies have become current strategies in the municipality. The Matrix Support via 
Caps started after the 2008 disaster from the need to decentralize actions that were strongly centralized in the Caps and in this way broaden psychosocial care in basic care.

In the beginning there were two teams for Matrix in the entire municipality; nowadays there are four multiprofessional teams of Capsi, Caps II, Capsad, and the Service of Mental Health Evaluation. An annual schedule is prepared that reaches an average of $50 \%$ of the units per year, around 33 Basic Health Units (UBS). The plan is to foment psychosocial care in the Family Health Teams (EqSF) and in the general ambulatory units.

This Matrix configuration via Caps and Secretariat of Health Care (SAS) differs from most municipalities in Brazil, where the Nucleus of Family Health Support (Nasf) has the Matrix Support as one of its objectives. Nasf was instituted by Ordinance GM nr 154, of January 24, 2008, and it was created to support and extend the reach, territorialization, and resoluteness of the EqSF of the Health Care Network (RAS) ${ }^{\mathbf{2 5}}$.

It is important to highlight the significance of Matrix Support in the Brazilian RAS policy. According to the guidelines for the organization of SUS Network, displayed in Ordinance $\mathrm{nr} 4279 / 2010$, as previously mentioned in this study, "it is necessary to consider and enhance [...] matrix support in order to build ways to have co-responsibilities of the professional and the user"25.

Therefore, Matrix Support is an important strategy used by the municipality; it is comprehensive and demands an interchange between professionals, which will help in the integrality of mental health care. According to Campos, Matrix Support enhances the bond and the horizontalization of care, and it aims to "ensure, in a dynamic and interactive way, a specialized background support to reference teams and professionals"26(77).

Matrix Support, categorized as health strategy, only considers secondary care to individuals who are already developing symptoms triggered by the disaster situation; this highlights the inexistence of planning for the development of health actions for prevention and performance during the occurrence of a disaster.

Besides Matrix Support, another work strategy of the health sector is Permanent Education that provides courses and capacitation for professionals to work in disaster situations. Permanent Education in this case has been a discontinued strategy with disruptions through time and without continuity ${ }^{27}$.

These courses do not occur in a systematic way; they are offered to all health professionals and depend on the professional's interest to enroll. The main initiative for the courses to be offered is from the Secretariat of Health through the Humanitarian Aid team.

The capacitation activities were categorized as health strategy but appear as nonencompassing, since not all professionals participate and they happen in a non-systematic way, meaning they occur sporadically.

It should be reiterated what is mentioned by the Ministry of Health ${ }^{\mathbf{2 8}}$ about the responsibility of the health sector to provide capacitation preventively and not only for the health services but also for other sectors that work in disaster situations, in accordance with the objectives of Sendai and Hyogo Frameworks that preconize disaster prevention and preparedness ${ }^{18}$.

It is important to highlight that considering that the locality has been facing countless disaster situations, the strategy should be one of Permanent Education, which differs from Continued Education insofar as it is a strategy without disciplinary fragmentation; its approach is more encompassing and it aims practice as source of knowledge, according to Ordinance $\mathrm{nr} 198 / 2004$, that creates the National Policy of Permanent Education in Health as a strategy of SUS ${ }^{29}$.

It is understood that professionals from all areas (health, firefighters, civil defense, Mobile Emergency Care Service - Samu, among others) can and should work providing 
care that complies with basic notions of psychological care as to prevent future aggravations such as syndromes and disorders.

It is not about offering specialized services such as psychiatric or psychological consultation to all those persons affected by a disaster; but it is necessary to provide the population with psychosocial care with the objective of reducing stress and the rise of possible psychological disorders, help people with the organization of a new routine, and, depending on the demand, with the elaboration of losses and grief, among other issues.

The need for psychosocial support demands the understanding that the affected persons must elaborate the painful experiences caused by these events, respecting their manifestation of pain, not victimizing, but rather helping to tackle distress according to each one's singularity and socio-cultural resources ${ }^{7}$.

This support is named Psychological First Aid (PFA) by Esfera Project ${ }^{30}$. It is about the support that must be provided immediately after the occurrence of a disaster and it is directed to individuals who are in psychological distress. It is not considered to be a clinical intervention nor a psychiatric emergency ${ }^{8}$.

Any person can apply PFA method as long as having received the proper training; thus, it would be an important method to be included in the training of all professional areas working in a disaster situation, such as Fire Brigade, Civil Defense, Basic Health Care, among others.

From the analysis of the interviews conducted in this study it was observed that the professionals have difficulty in providing mental health care or support to someone in need while performing their activities in a disaster situation. Therefore, PFA can be considered an important psychosocial support as means of preventing possible future aggravations and for the evaluation of cases that need to be referred to a specialized mental health service.

\section{Final considerations}

This study has revealed the perception of workers on the experience of the population in the 2008 tragedy in Itajaí Valley, state of Santa Catarina, Brazil, highlighting the impacts on mental health reflected by the process of life interruption and exposure to consequences that amplified the potential for mental disorder in those affected. The notification of a significant increase in the population's demand, in particular for mental health services, the aggravation of preexisting conditions undergoing treatment before the disaster, and the occurrence of new cases of mental disorder show the relevance of the theme for professional health education. The study also reveals that the importance of delivering mental health care in the professional's daily practice, during and after the occurrence of the disaster, is challenged by the lack of contingency plans involving professionals in mental health actions and training of teams for this kind of event.

We also observed that the municipality has taken into consideration those experiences in the process of reformulating and updating the strategies. Matrix Support and Permanent Education have been put into effect and are seen as important tools for the population and workers involved in disaster situations. When professionals are provided with appropriate support to perform their work, the population will have the means to deal with reality with greater possibility of risk reduction in all contexts of a disaster.

The lack of structured and coordinated qualification to deliver mental health care in disasters reflects in uncoordinated actions in the post-disaster reality, not taking into consideration the potentialities of the event for the population's reintegration. Hence, training prepares workers to deal with the crisis, by promoting the population's health in the process of restarting life from the point where it is in the post-disaster. Therefore, the support of professionals requires close attention to 
the disorders of team workers as part of the population directly or indirectly affected; they also need care in these situations, considering their potentialities for resilience at work and community conviviality in the face of disasters.

\section{Collaborators}

Rafaloski AR (0000-0002-4922-4166)* contributed to the conception of the study, data collection, data analysis and interpretation, discussion of outcomes, writing and critical review of contents, revision and approval of final version. Zeferino MT (0000-00030161-5931)* contributed to the conception of the study, analysis and interpretation of data, discussion of outcomes, writing and critical review of contents, revision and approval of final version. Forgearini BAO (0000-0001-9592-2603)*, Fernandes GCM (0000-0003-0445-1610)* and Menegon FA (0000-0003-4516-6162)* contributed equally to the elaboration of the manuscript.

\section{References}

1. Brasil. Lei ${ }^{\circ} 12.608$, de 10 de abril de 2012. Ministério de Integração Nacional. Secretaria Nacional de Proteção e Defesa Civil. Política Nacional de Defesa Civil. Diário Oficial da União. 11 Abr 2012.

2. Beniakar M, Collazo C. Salud mental em desastres: Problemáticas, paradojas y perspectivas clínicas. In: Benikar M, Thomé JT, Taralli IH. Intervenção em situações limite desestabilizadoras: crises e traumas. Rio de Janeiro: ABP; 2009.
3. McKinzie AE. In their own words: disaster and emotion, suffering, and mental health. Int J Qual Stud Health and Well-being. 2018; 13(1):1440108.

4. Rodríguez J, Davoli, MZ, Pérez, R. Organización Panamericana de La Salud. Guía práctica de salud mental en desastres [internet]. Washington, DC: OPAS; 2009. [acesso em 2019 maio 26]. Disponível em: https://iris.paho.org/handle/10665.2/2800.
${ }^{\star}$ Orcid (Open Researcher and Contributor ID). 
5. Fernandes GCM, Boehs AE, Sharon AD, et al. Rural families interpretations of experiencing unexpected transition in the wake of a natural disaster. Cad. Saúde Pública [internet]. 2017 [acesso em 2019 ago 2]; 33(1):e00161515. Disponível em: http://dx.doi. org/10.1590/0102-311x00161515.

6. Avila MRR, Mattedi MA. Desastre e território: a produção da vulnerabilidade a desastres na cidade de Blumenau/SC. urbe, Rev. Bras. Gest. Urbana [internet]. 2017 [acesso em 2019 ago 2]; 9(2):187-202. Disponível em: http://dx.doi.org/10.1590/2175-3369.009.002.ao03.

7. Noal DS, Oliveira SS, Alpino TMA, et al. Gestão Local de Desastres Naturais para a Atenção Básica [internet]. São Paulo: UNASUS; UNIFESP; 2016. Disponível em: https://www.arca.fiocruz.br/bitstream/ icict/37492/2/Curso\%20AB.pdf.

8. Organização Pan-Americana da Saúde; Ministério da Saúde. Desastres Naturais Saúde no Brasil [internet]. Brasília, DF: OPAS; Ministério da Saúde; 2015. [acesso em 2017 jun 27]. Disponível em: http://semiarido. icict.fiocruz.br/wp-content/uploads/Desastres-e-Sa\%C3\%BAde-Brasill.pdf.

9. Organización Mundial de La Salud, Organización Panamericana de La Salud. Plan de Operaciones de Emergencia de La Red de Servicios de Salud. Guia para la Planificación. Lima: MS; 2014. [acesso em 2017 jun 28]. Disponível em: https://cursospaises.campusvirtualsp.org/pluginfile.php/71516/mod_page/content/8/plan_emergencia_red_servicios_salud.pdf.

10. Brasil. Secretaria de Direitos Humanos. Protocolo Nacional Conjunto para Proteção Integral de Crianças e Adolescentes, Pessoas Idosas e Pessoas Com Deficiência em Situação de Riscos e Desastres. Brasília, DF: SDH; 2013.

11. Brasil. Secretaria de Vigilância em Saúde. Guia de preparação e resposta aos desastres associados às inundações para a gestão municipal do Sistema Único de Saúde. Brasília, DF: SVS; 2011.

12. Instituto Brasileiro de Geografia e Estatística. Panorama População [internet]. 2015. [acesso em 2016 jun
26]. Disponível em: http://cidades.ibge.gov.br/xtras/ temas.php?lang $=\&$ codmun $=420820$ \&idtema $=16 \&$ se arch=sant a-catarina|itajai| sintese-das-informacoes.

13. Instituto Brasileiro de Geografia e Estatística. Censo Demográfico 2015. Síntese de Informações [internet]. Brasília, DF: IBGE; 2015. [acesso em 2016 jun 26]. Disponível em: http://cidades.ibge.gov.br/xtras/temas. php?lang $=\& \operatorname{codmun}=420820 \&$ idtema $=16 \&$ search $=\mathrm{s}$ ant a-catarina|itajai|sintese-das-informacoes.

14. Universidade Regional de Blumenau. Cota-enchente de Blumenau. Blumenau: Furb; 2012. [acesso em 2016 jun 30]. Disponível em: http://ceops.furb.br/cotas/ Relatorio_Final_Cotas_Enchentes-09-11-2012.pdf.

15. Vinuto J. A amostragem em bola de neve na pesquisa qualitativa: um debate em aberto. Temáticas. 2014; 22(44):203-220.

16. Bardin L. Análise de conteúdo. Lisboa: 70. Ed.; 2011.

17. Conselho Nacional de Saúde. Resolução no 466, de 12 de dezembro de 2012. Comissão Nacional de ética em Pesquisa. [acesso em 2016 maio 16]. Disponível em: http://conselho.saude.gov.br/resolucoes/2012/ Reso466.pdf.

18. Trajber R, Olivato D, Marquezine V. Conceitos e termos para a gestão de riscos e desastres na educação. Centro Nacional de Monitoramento e Alertas de Desastres Naturais [internet]. São Paulo: CEMADEN; 201[?]. [acesso em 2019 ago 26]. Disponível em: http://educacao.cemaden.gov.br/medialibrary_publication_attachment?key=EDtGLgxTQiYlb8yFZUCU NDldSaw $=>$.

19. Vasconcelos TP, Cury VE. Atenção Psicológica em Situações Extremas: Compreendendo a Experiência de Psicólogos. Psicol. Ciênc. Prof [internet]. 2017 [acesso em 2019 ago 19]; 37(2):475-488. Disponível em: http://dx.doi.org/10.1590/1982-3703002562015.

20. Freud S. Os Pensadores: Cinco lições de psicanálise, A história do movimento psicanalítico, O futuro de uma ilusão, O mal-estar na civilização, Esboço de psicanálise. São Paulo: Abril Cultural; 1978. 
21. Gonçalves C. Regiões, cidades e comunidades resilientes: novos princípios de desenvolvimento. Rev. Bras. Gest. Urbana [internet]. 2017; 9(2):371-385. [acesso em 2017 dez 5]. Disponível em: http://dx.doi. org/10.1590/2175-3369.009.002.ao15.

22. Pereira CAR, Barata MML. Organização dos serviços urbanos de saúde frente à mudança do clima e ao risco de desastres na América Latina. Saúde debate [internet]. 2014 [acesso em 2019 ago 26]; (38)102:67. Disponível em: http://dx.doi.org/10.5935/01031104.20140057.

23. Munro A. Effect of evacuation and displacement on the association between flooding and mental health outcomes: a cross-sectional analysis of UK survey data. Lancet Planet Health [internet]. 2017; 1(4):134141. Disponível em: https://www.ncbi.nlm.nih.gov/ pubmed/28944321.

24. Souza Minayo SC. O desafio do conhecimento: Pesquisa qualitativa em saúde. São Paulo: Hucitec; 2010.

25. Brasil. Ministério da Saúde, Secretaria de Atenção à Saúde, Departamento de Atenção Básica. Diretrizes do NASF: Núcleo de Apoio à Saúde da Família [internet]. Brasília, DF: MS; 2010. [acesso em 2019 abr 1]. Disponível em: http://bvsms.saude.gov.br/bvs/publicacoes/caderno_atencao_basica_diretrizes_nasf.pdf.

26. Campos GWS. Clínica e saúde coletiva compartilhadas: teoria Paidéia e reformulação ampliada do trabalho em saúde. In: Campos GWS, Bonfim JRA, Minayo MCS, et al., organizadores. Tratado de saúde coletiva. 2. ed. São Paulo: Hucitec; 2012. p. 39-78.
27. Brasil. Ministério da Saúde, Secretaria de Gestão do Trabalho e da Educação na Saúde. Política Nacional de Educação Permanente em Saúde [internet]. Brasília, DF: MS; 2009. [acesso em abr 1]. Disponível em: http://bvsms.saude.gov.br/bvs/publicacoes/pacto_ saude_volume9.pdf.

28. Brasil. Ministério da Saúde, Secretaria de Vigilância em Saúde. Guia de preparação e resposta aos desastres associados às inundações para a gestão municipal do sistema único de saúde 2011[internet]. Brasília, DF: MS; 2011. [acesso em 2019 abr 1]. Disponível em: https://portalarquivos.saude.gov.br/images/pdf/2017/ junho/08/Guia_para_sms_desastres_julho_2011.pdf.

29. Brasil. Ministério da Saúde. Portaria $n^{0} 198$, de 13 de fevereiro de 2004. Institui a Política Nacional de Educação Permanente em Saúde como estratégia do Sistema Único de Saúde para a formação e o desenvolvimento de trabalhadores para o setor e dá outras providências. Diário Oficial da União. 14 Fev 2004.

30. Esfera. El Proyecto Esfera. Carta Humanitaria y normas mínimas para la respuesta humanitaria. Reino Unido: Proyecto Esfera; 2011.

\footnotetext{
Received on 09/23/2019

Approved on 03/05/2020

Conflict of interests: non-existent

Financial support: non-existent
} 